\section{Fiscaoeconomia}

E-ISSN: 2564-7504

2021, Volume 5, Issue 2, 630-651

https://dergipark.org.tr/tr/pub/fsecon
Research Article/Araştırma Makalesi

Submitted/Geliş: 03.02.2021

Accepted/Kabul: 17.02.2021

Doi: $10.25295 /$ fsecon. 873942

\title{
Vergi Kaçakçılık Suçlarında Soruşturma Evresi
}

Investigation Phase in Tax Evasion Crimes

Taha Emre ÇiFTçi ${ }^{1}$

Öz

Vergi kaçakçılık suçları, Vergi Usul Kanunu (VUK) m. 359'da belirtilen suç tiplerinin ihlal edilmesi ile ortaya çıkar. Vergi kaçakçıı suç fiillerinin ortaya çıkması neticesinde yargılama yapılabilmesi, yasa koyucu tarafından bazı şartlara bağlanmış̧ır. Bu kapsamda VUK m. 367 kaçakçılık suçu fiillerine yönelik soruşturma ve kovuşturma şartlarını içeren bir düzenlemedir. Bu düzenleme, vergi kaçakçılığı suçlarının muhakeme aşamasına geçebilmesi için mütalaa veya görüş şartı öngörmüştür. Bu çalışmada, kaçakçılık suç fiilinin tespiti ile kovuşturma aşamasına kadar süren hukuki sürece ilişkin değerlendirmeler yapılmıştır.

Jel Kodları: $K 34, H 26, K 42$.

Anahtar Kelimeler: Vergi Kaçakçılık Suçları, Kovuşturma Şartı, Soruşturma Evresi.

\section{Abstract}

Tax evasion crimes occur with the violation of the crime types specified in the clause of 359 of Tax Procedure Law of Turkey. The ability to prosecute as a result of tax evasion crimes is bound by some conditions by the legislator. In this context, the clause of 367 of Tax Procedure Law is a regulation that includes investigation and prosecution conditions for acts of tax evasion. This regulation stipulated a notion or opinion requirement in order for the tax evasion crimes to be proceeding to the trial stage. In this study, evaluations are made regarding the legal process that lasts from the detection of the evasion crime and the prosecution stage.

Jel Codes: $K 34, H 26, K 42$.

Keywords: Tax Evasion Crimes, Prosecution Condition, Investigation Stage.

\footnotetext{
${ }^{1}$ Dr. Öğr. Üyesi, Necmettin Erbakan Üniversitesi, Uygulamalı Bilimler Fakültesi, Muhasebe ve Finans Yönetimi Bölümü, teciftci@erbakan.edu.tr, ORCiD: 0000-0002-6548-9017
}

Citation/Atıf: Çiftçi, T. E. (2021). Vergi kaçakçılık suçlarında soruşturma evresi. Fiscaoeconomia, 5(2), 630-651. doi: 10.25295/fsecon.873942 


\section{Giriş}

Devletin hizmet sunumlarını sağlayabilmesi açısından vergi gelirlerinin payı büyüktür. Bu bakımdan vergi tahsilatının sağlıklı bir şekilde işleyebilmesi için, vergilendirme süreci içinde bir düzenin varlığı gereklidir. Devlet vergilemeye ilişkin bu düzeni sağlayabilmek için mükelleflerine ve sorumlularına kurallar koymuştur. Yasa koyucu tarafından ortaya çıkarılan kurallar vergi ödevlerinin zamanında, eksiksiz ve bir düzen içinde sağlanabilmesine yöneliktir. Vergi mükellefleri ve sorumluları, üzerlerine yüklenen görevleri kanunun çizdiği sınırlar dahilinde gerçekleştirmeleri gerekmektedir. Kanunla belirlenen görevlere aykırı hareketler için yaptırımlar düzenlenmiştir. Bu yaptırımların amacı, vergisel görevlere uyulmasına yönelik caydırıcılık özelliğinin ön plana çıkarılmasıdır. Bu nedenle idari düzenin sağlanması için belirlenen idari para cezaları ile kamusal düzenin sağlanması için belirlenen hapis ve/veya adli para cezaları vergi ceza hukuku içinde yer alan yaptırım türlerini oluşturmaktadır.

Suç ve cezalara ilişkin genel düzenlemeler Türk Ceza Kanunu (TCK) kapsamı içinde yer almaktadır. Ancak, ceza kanunu dışında bazı kanunlarda da suç ve cezalara yönelik hükümler bulunmaktadır. Bu şekilde diğer kanunlarda bulunan suç ve cezalar genel ceza hukukunun tamamlayıcısı niteliğindedir. Vergi ceza hukuku kapsamında VUK'ta yer alan vergi suçları ve cezaları da tamamlayıcı suç ve ceza özelliği taşımaktadır (Kızılot ve Taş, 2010: 111). Bu kapsamda TCK genel bir ceza kanunu olmakla birlikte VUK (ceza hükümlerinin yer aldığı dördüncü kitabı) özel bir ceza kanunudur (Şenyüz, 2012: 382). Vergi ceza hukuku, vergi kanuna aykırılık taşıyan kabahat/suçlara ve bunlara uygulanan cezalara yönelik kuralların toplamı olarak ifade edilmektedir.

Vergi suç ve cezaları, "idari nitelikli" ve "adli nitelikli" olarak iki şekilde ayrıma tabi tutulmaktadır. Bu kapsamda idari yaptırım öngören vergi suçları kabahat niteliğindedir. Buna ek olarak adli yaptırım gerektiren vergi suçları ise cürüm niteliğindedir (Arslaner, 2017: 83). Vergi kabahatleri, vergi ödevlilerinin vergi kaybını ve vergi kaybı tehlikesini esas alarak oluşturulmuştur. Bu kabahatler, idari düzeni sağlamaya yönelik hafif nitelikteki yaptırımları içerir. Bununla birlikte, idari usuller çerçevesinde vergi idaresi tarafından uygulanan yaptırım idari para cezasıdır. Vergi suçları kamu düzenini bozucu eylemleri içerdiğinden bu suçların yaptırımı kabahatlere göre ağırdır. Vergi suçlarının eylemlerine yönelik cezaların uygulanması ceza mahkemeleri aracılığıyla gerçekleştirilmektedir. Yani bu tür ağır nitelikli eylemlerde ortaya çıkan uyuşmazlık yargı organlarınca çözüme kavuşturulacaktır.

Vergi ceza hukukunda vergisel ödevlerin yerine getirilmesini sağlamak amacıyla uygulanan idari para cezalarının vergi kaçakçılık suçlarında caydırıcı olamayacağı görülmüştür (Mutluer ve Kuzeyli, 2019: 226). Kaçakçılık suç fiilleri kamu düzenini bozan ve devlet otoritesini etkileyen nitelikte olmasından dolayı, bu türlü vergi suçlarına uygulanacak yaptırımın daha ağır olması gerekir. Nitekim yasa koyucu kaçakçılık suçu fiillerine yönelik hürriyeti bağlayıcı cezalar uygulanmasını öngörmüştür.

Vergi kaçakçılık suçlarında ağır yaptırım, kamusal düzenin sağlanmasına yönelik suç önleme ve vergi güvenliği sağlama açısından önem arz etmektedir. Vergi kaçakçılık suçları Vergi Usul Kanunu (VUK) m. 359'da düzenlenmiştir. Bu kanun hükmünde ayrıca vergi kaçakçılık suçlarının fiilleri ile birlikte bu suç fiillerine yönelik öngörülen cezalar da yer almaktadır. VUK m. 359'a aykırı hareket edenler, ceza hukuku anlamında suç oluştururlar. Bu suçu işleyenler kanunun 
Çiftçi, T. E. (2021). Vergi kaçakçılık suçlarında soruşturma evresi.

Fiscaoeconomia, 5(2), 630-651 doi: 10.25295/fsecon.873942

öngördüğü hapis cezası ile cezalandırılırlar. Ayrıca bu suçların işlendiğine ve cezalandırılmasına yönelik karar, ceza mahkemelerince verilmektedir (Karakoç, 2019: 292).

Vergi kaçakçılık suçlarının usul yönünden soruşturma ve kovuşturma şartı olarak VUK m. 367 esas alınmaktadır. Bu kanun hükmü, vergi kaçakçııık suç fiilinin tespiti halinde soruşturma ve kovuşturma şartlarını içeren bir düzenlemedir. VUK m. 359'da yer alan vergi kaçakçılık fiillerinin vergi incelemesine yetkili olan kişilerce tespit edilmesi halinde mütalaanın Cumhuriyet Başsavcılığı'na verilmesi, soruşturma ve kovuşturma şartını oluşturmaktadır. Ayrıca, vergi kaçakçılık suç fiilinin Cumhuriyet başsavcılığı tarafından öğrenilmesi halinde vergi idaresine durum bildirilerek vergi incelemesinin talep edilmesi ve bu kapsamda görüş alınması da soruşturma ve kovuşturma şartıdır.

Bu çalışmada öncellikle vergi suçları açıklanarak VUK 359'da düzenlenen vergi kaçakçılık suçları ele alınmıştır. Çalışmanın diğer kısmında, vergi kaçakçılık suçlarının takibi VUK m. 367 hükümleri çerçevesinde incelenerek gerekli değerlendirmeler yapılmaya çalışılmıştır.

\section{Vergi Suçları}

Suç, kanunların cezalandırdığı fiil olarak tanımlanmaktadır. Bu bakımdan suçu, cezai yaptırım ile korunan normlara uymama olarak da ifade etmek mümkündür. Cezai yaptırımla hangi normların korunacağına, kamu çoğunluğunun düşüncesini yansıtan yasa koyucu belirlemektedir (Mutluer, 2008: 213).

Bir eylemin suç sayılabilmesi için, eylemi gerçekleştiren kişinin kusurlu iradesinin olması, kanunda yazılı suç tipine uygun bulunması ve yaptırım olarak cezanın uygulanmasını gerektirmesi gereklidir (Candan, 2019: 65)².

Vergilerin zorunlu olarak alınmaya başlanmasıyla birlikte vergi yükümlülüğünün görev ve özveri karakteri artmaya başlamıştır. Bununla birlikte zorunluluğa uymayan veya uymak istemeyenler vergi kaybına neden olarak bu şekilde vergi suçunun da ortaya çıktığı söylenebilir (Mutluer, 2008: 222).

Vergi suçları, VUK ve diğer vergi kanunlarında belirtilen görev ve ödev hükümlerine aykırılıktan doğmaktadır (Tosuner ve Arıkan, 2006: 265). Yasa koyucu idari düzeni ve kamusal düzeni sağlamak için vergisel suçlara yönelik farklı yaptırımlar düzenlemiştir. İdari düzeni ihlal eden eylemler hafif nitelikteki yaptırımı öngören vergi kabahatlerini oluşturur. Bu bakımdan, hazinenin menfaatini korumak ve idari düzeni sağlamak amacıyla vergi kabahatine yönelik yaptırım için idari para cezası düzenlenmiştir. Vergi kaybı ortaya çıksın veya çıkmasın devlet otoritesini sarsan ve kamu düzenini bozan ihlaller vergi suçları kapsamındadır. Vergi suçlarına yönelik ağır ihlal niteliği taşıyan eylemlere uygulanacak yaptırım ise hürriyeti bağlayıcı cezalar ve/veya adli para cezalarıdır.

Vergi suçlarına ilişkin düzenlenen ağır yaptırım, hukuki yararın sağlanmasında etkili olacaktır. Vergi suçları kapsamında yer alan suçlardan özellikle vergi kaçakçılık suçunun fiilleri devletin gelir kaybına neden olabilmektedir. Ayrıca, kamusal hizmetlerin finansmanı da çoğunlukla

\footnotetext{
${ }^{2}$ Candan (2019) bu ifadeyi, Uğur ALACAKAPTAN'ın suç tanımından yola çıkarak açıklamıştır. Alacakaptan'ın suç tanımı şu şekildedir: "Suç isnad yeteneğine sahip bir kişinin kusurlu iradesinin yarattığı icraî veya inmali bir hareketin meydana getirdiği yasada yazılı tipe uygun, hukuka aykırı ve müeyyide (yaptıım) olarak bir cezanın uygulanmasını gerektiren bir eylemdir".
} 
Çiftçi, T. E. (2021). Vergi kaçakçılık suçlarında soruşturma evresi.

Fiscaoeconomia, 5(2), 630-651 doi: 10.25295/fsecon.873942

vergilerden karşılandığı düşünüldüğünde vergi kaçakçılık suçuyla oluşan hazine zararı neticesinde topluma yönelik bir zarardan söz edilebilir. Bununla birlikte vergi kaçakçılık suçunda ağır yaptırımın caydırıcı özelliği, suçun önlenmesinde de etkin rol oynamaktadır. Bu bakımdan vergi kaçakçılık suçunda, hukuki yararın ve kamu düzeninin sağlanması açısından yaptırımın ağırlığı önem arz etmektedir.

Kamu düzenini bozan ve ağır ihlal yaptırımı içeren vergi suçları, ceza hukuku anlamında suç niteliğindedir. Suç olarak nitelendirilen ağır ihlallere ceza hukuku ilkelerine göre işlem yapılmaktadır (Şenyüz, 2012: 5). Bu tür suçların yargılanması ceza mahkemelerince yürütülmekte ve mahkeme kararı olmaksızın kişiye cezai yaptırım uygulanamaz (Arslaner, 2017: 30).

Bir eylemin suç olabilmesi ya da bir kişinin fail olabilmesi için suç unsurlarının bir arada bulunması şarttır. Bu bakımdan, suçun unsurlarında biri veya birkaçının eksik olması eylemin suç niteliğini bozacaktır. Bir eylemin suç olarak kabul edilebilmesi için kanundaki tipe uygun, hukuka aykırı ve kusurlu bir fiilin bulunması gerekir. Bu açıdan, kanuni unsur (tipiklik), maddi unsur (fiil), manevi unsur (kusur) ve hukuka aykırılık unsurları suçun oluşumu için gerekli unsurlardır (Şenyüz, 2012: 386). Suçun tüm unsurlarını taşıyan bir fiil tespit edildiğinde kanunun öngördüğü ceza yaptırımı belirlenecek ve uygulanacaktır (Üstün, 2001: 299). Dolayısıyla, vergi suçu kapsamında mahkemelerin ceza verme yetkisi ancak bu dört unsurun bir araya gelmesiyle devreye girecektir.

Vergi Usul Kanunu'nda düzenlenen vergi suçları genel itibariyle şu şekildedir:

- Kaçakçılık suçları (VUK, m. 359),

- Vergi mahremiyeti ihlal suçu (VUK, m. 362),

- Mükellefin özel işlerini yapma suçu (VUK, m. 363).

Vergi kaçakçılığı suçuna ilişkin hareketin tipi ve cezası VUK'ta yer bulmaktadır. Ancak, vergi mahremiyeti ihlal ve mükellefin özel işlerini yapma suçlarına yönelik hareket tipleri VUK'ta bulunmakla birlikte cezası TCK'nın 239 ve 257. maddelerine gönderme yapılarak tespit edilmiştir (Yüce, 2018: 28).

\section{Vergi Kaçakçılık Suçları}

\subsection{Genel Olarak}

Vergiyi doğuran olayı gerçekleştiren mükellef üzerine düşen vergi yükünü azaltabilmek için çeşitli yollara başvurabilmektedir. Bu yollardan biri vergiden kaçınmadır. Mükellef bu durumda yasal sınırlar içinde hareket ederek vergiden kaçınabilmektedir. Vergiden kaçınan mükellef yasalara aykırı hareket etmediğinden dolayı vergisel suç ortaya çıkmaz. Bir diğer yol ise vergi kaçırmadır. Vergi mükellefi veya sorumlusu, yasal kuralları ihlal ederek vergi ödememek ya da az ödemek için vergi kaçırmaktadır (Akdeniz, 2018: 93). Dolayısıyla bu durumda hukuka aykırı hareket eden mükellefler için vergisel suç ortaya çıkmaktadır.

Hapis cezası gerektiren suçlar ve bu suçlara ilişkin cezalar VUK'un Dördüncü Kitabının "Suçlar ve Cezaları" bölümünde yer almaktadır. Ayrıca bu bölüm içinde bulunan "Kaçakçılık Suçları ve Cezaları" vergi suçları ve cezaları kapsamında en ağır yaptırıma tabi tutulan suç eylemlerini içinde barındırmaktadır. 
Çiftçi, T. E. (2021). Vergi kaçakçılık suçlarında soruşturma evresi.

Fiscaoeconomia, 5(2), 630-651 doi: 10.25295/fsecon.873942

Kaçakçılık suçu, geçmişten günümüze değişik ad ve niteliklerle varlığını devam ettirmiştir (Karakoç, 2019: 296). Nitekim vergi kaçakçılık suçu geçmişte idari ve mali nitelikteki yaptırımından günümüzde hürriyeti bağlayıcı ceza niteliğine kadar yasa koyucu tarafından belirlenen düzenlemeleri mevcuttur ${ }^{3}$. Vergi kaçakçılık suçuna ilişkin en önemli değişiklik 22.07.1998 tarih ve 4369 sayılı yasa değişikliğidir. Bu yasa değişikliği öncesinde, VUK'un m. 359 'da bulunan bir fiilin suç kapsamında olabilmesi için kasten işlenmesi ve vergi kaybına sebebiyet vermesi gerekmekteydi. Ancak söz konusu yasa değişikliği ile vergi kaybının suçun bir unsuru olması gerektiği kaldırılmış ve kasten ibaresi de madde metninden çıkarılmıştır. Bu değişiklik vergi kaçakçılık suçunun zarar suçu niteliğini tehlike suçuna dönüştürmüştür (Acar, 2020: 671). Bu bakımdan suçun toplumsal değerin ihlali neticesinde hukuksal yarara sadece zarar veren eylemlerin değil, tehlikeye sokan eylemlerin de cezalandırılmasını gerektirmiştir (Öz ve Armağan, 2018). Her ne kadar kasten ibaresi yasa metninden çıkarılmış olsa da vergi kaçakçılığı suçunun ceza hukuku anlamında bir suç olması nedeniyle suçun oluşabilmesi için failin eyleminde kastın aranacağı açıktır (Ağar, 2005: 281).

Mali anlamda vergi kaçakçılığı, vergi kanunlarına aykırı hareket ederek vergilendirilebilir gelir ve servetin vergi idaresinin bilgisi dışında bırakılması veya vergi matrahının gizlenmesi amacıyla hileli işlemlere başvurulması olarak ifade edilmektedir (Öz ve Armağan, 2018 (Naklen); Köşşekoğlu, 2011: 2). Vergi kaçakçılık suçları, kanunda tipi gösterilen davranış biçimiyle vergi kanunlarına aykırı hareketle ortaya çıkmaktadır (Candan, 2019: 358). Bu tür suçlar, genellikle vergi mükellefi ve sorumluları tarafından işlenebilen objektif sorumluluğa dayalı, kendine özgü özellikleri olan suçlardır (Taştan, 2013: 41).

Genel anlamda vergi gelirlerini azaltıcı faaliyetler ekonomik suç kapsamında vergi suçu olarak ifade edilmektedir. Ekonomik suçlar için ekonomik ceza ilkesi ön plana çıkarılmışsa da vergi suçlarında yaptırım olarak hürriyeti bağlayıcı cezalar uygulanmaktadır. Çünkü vergilendirme karşısında sahteciliğe ve hileli yollara başvuranlara mali yaptırımlarla cezalandırmak yeterli olmaz (Şenyüz, 2012: 381). Bu kapsamda ihlalin ağır niteliği itibariyle vergi kaçakçılığı eylemlerine yönelik mali nitelikteki cezaların caydırıcılık etkisi düşük olacağından bir çok devlet bu konuda ağır yaptırımlı cezai önlemler alma yoluna gitmişlerdir (Mutluer, 2008: 301).

Yasa koyucu, vergi kaçakçılığı suçunun oluşumunda vergi kaybını zorunlu tutmamıştır. Bir başka ifadeyle, tarh döneminden önce fiillerin ortaya çıkarılması da vergi kaçakçılı̆ı kapsamında girmektedir (Bilici, 2020: 118). Vergi kaybı ortaya çıkarsın veya çıkarmasın devlet otoritesini sarsmaya ve kamu düzenini bozmaya ilişkin eylemler vergi suçu olarak yasa koyucu tarafından belirtilmiştir. Bu bakımdan vergiyi hileli ve sahte yöntemlerle kaçırmaya yönelik eylemler VUK 359'da vergi suçu olarak belirlenmiş ve bu vergi suçunun cezası da yine aynı maddede yer bulmuştur.

\subsection{Vergi Kaçakçılık Suçlarının Fiilleri}

VUK m. 359'da bulunan kaçakçılık suçlarının oluşumu için vergi kaybının varlığı gerekli değildir. Vergi ziyaı ortaya çıkmamış olsa bile, eylemin yapılmış olması suçun maddi unsuru için yeterli sayılmaktadır. Bu durumun nedeni, yasa koyucu tarafından vergi kaçakçılık suçunda kamu düzenin gözetilmesidir (Candan, 2019: 372).

\footnotetext{
${ }^{3}$ Ayrıntılı Bilgi için bkz. Karakoç, 2019: 296-299.
} 
Çiftçi, T. E. (2021). Vergi kaçakçılık suçlarında soruşturma evresi.

Fiscaoeconomia, 5(2), 630-651 doi: 10.25295/fsecon.873942

Mükellefin, vergi sorumlusunun veya bunlarla hukuki ilişkide bulunan diğer kişilerin eylemlerinde kaçakçılık suçunun oluşabilmesi için, vergi kanunlarına göre tutulması, düzenlenmesi, muhafaza edilmesi ve ibraz edilmesi gereken defter, kayıt ve belgeler ile ilgili olması yeterli değildir. Buna ek olarak vergi kaçakçılık suçunun oluşabilmesi için VUK m. 359'da eylem tipleriyle de uyumlu olması gerekmektedir (Candan, 2019: 358).

Vergi kaçakçılık suçunun fiilleri VUK m. 359'da yer almaktadır. Bu madde içeriği vergi kaçakçılık fiillerine ait eylem tiplerini belirtmekle birlikte fiillere yönelik cezaları da içermektedir. Vergi kaçakçılık suçlarına ilişkin konular ve failin eylemleri birçok farklı türde ortaya çıkmaktadır. Vergi kaçakçılığı suçları VUK m. 359'da belirtilen ihlaller ile ortaya çıkmaktadır. Bu kanun hükümlerine aykırılık VUK m. 359'dan hareketle vergi kaçakçılık suçunun konuları, faili ve cezaları aşağıdaki şekilde açıklanabilmektedir.

\subsubsection{On sekiz aydan üç yıla kadar hapis cezası gerektiren kaçakçılık suçlarının fiilleri}

VUK m. 359/a fıkrasında, vergi kanunlarına göre tutulan veya düzenlenen ve saklanma ve ibraz mecburiyeti bulunan defter ve kayıtlarda kaçakçılık suçu gerektiren hareket tiplerini belirten fiiller yer almaktadır. Vergi kaçakçılık suçlarında alt sınır cezai yaptırım gerektiren eylemler bu grupta yer almaktadır. Bu kanun hükmü uyarınca on sekiz aydan üç yıla kadar hapis cezası gerektiren ihlaller yasa koyucu tarafından aşağıdaki şekilde belirlenmiştir.

- Defter ve kayıtlarda hesap ve muhasebe hileleri yapılması,

- Defterlerde gerçek olmayan veya kayda konu işlemlerle ilgisi bulunmayan kişiler adına hesap açılması,

- Defterlere kaydı gereken hesap ve işlemleri vergi matrahının azalması sonucunu doğuracak şekilde tamamen veya kısmen başka defter, belge veya diğer kayıt ortamlarına kaydedilmesi,

- Defter, kayıt ve belgeleri tahrif edilmesi,

- Defter, kayit ve belgelerin gizlenmesi,

- Muhteviyatı itibariyle yanıltıc belge düzenlenmesi veya bu belgelerin kullanılmasıdır.

\subsection{2. Üç yıldan beş yıla kadar hapis cezası gerektiren kaçakçılık suçlarının fiilleri}

VUK m. 359/b fıkrasında, vergi kanunları uyarınca tutulan veya düzenlenen ve saklama ve ibraz mecburiyeti bulunan defter, kayıt ve belgeler üzerinde kasten yapılacak eylemlerin tipleri belirtilmiştir. Bu hareket tiplerinin ihlali halinde VUK m. 359/a fıkrasında bulunan cezaya oranla daha ağır cezai yaptırım düzenlenmiştir. İlgili kanun hükmüne göre kaçakçılık suçu arz eden eylemler aşağıda belirtildiği gibidir.

- Defter, kayıt ve belgeleri yok edilmesi,

- Defter sahifelerini yok ederek yerine başka yapraklar konulması veya hiç yaprak konulmaması

- Belgelerin asıl veya suretlerini tamamen veya kısmen sahte olarak düzenlenmesi veya bu belgeleri kullanılmasıdır.

\subsection{3. İki yıldan beş yıla kadar hapis cezası gerektiren kaçakçılık suçlarının fiilleri}

VUK m. 359/b fıkrası gereğince Hazine ve Maliye Bakanlığı ile anlaşması bulunan kişilerin basabileceği belgeleri, Bakanlık ile anlaşması olmadığı halde basılması veya bilerek kullanılmasının yaptııımı iki yıldan beş yıla kadar hapis cezasıdır. Bu kanun hükmünde iki seçimlik eylem tipi öngörülmüştür. Bu kaçakçılık suçu öngören seçimlik hareketlerden biri, 
Çiftçi, T. E. (2021). Vergi kaçakçılık suçlarında soruşturma evresi.

Fiscaoeconomia, 5(2), 630-651 doi: 10.25295/fsecon.873942

belgelerin Hazine ve Maliye Bakanlığı ile anlaşması olmadığı halde basılmasıdır. Diğeri ise, Hazine ve Maliye Bakanlığı ile anlaşması olmadığı halde basılan belgelerin kullanılması fiilidir.

\subsection{Vergi Kaçakçılık Suçunun Faili}

Failin sözlük anlamı, "hukuki sonuç doğuracak bir suç işleyen kimse" olarak belirtilmektedir (https://sozluk.gov.tr/). TCK m. 37/1'de faillik, "Suçun kanuni tanımında yer alan fiili birlikte gerçekleştiren kişilerden her biri, fail olarak sorumlu olur." şeklinde açıklanmıştır.

Kanunlarda bulunan ceza normunu ihlal eden kişiye suçlu denilmekte ve bu suçu işleyen kişi faildir. Bir kişinin suç işleyebilmesi için hareket kabiliyetinin olması gerekir. Bu nedenle fail olabilmek için insan olmak ve hayatta bulunmak zorunludur. Bu kapsamda vergi suçlarında da "gerçek kişilerin" fail olabileceği açıktır (Şenyüz, 2012: 418).

Vergi cezalarında faillik, vergi kanunlarının normlarına uymayan kişileri kapsamaktadır. Vergi kanunlarında yapılmaması veya yapılması şeklinde oluşturulan normlara uymayan tarafların tümü fail kavramı içinde yer almakta ve cezalandırılmaktadır (Özel, 2010: 1175).

Kamusal vergi suçu olarak düzenlenen kaçakçılık suçunun yaptırımı, hapis ve/veya adli para cezasıdır. Hapis cezalarında kimlerin cezanın sorumlusu olabileceği TCK'nın ilgili düzenlemeleri kapsamında belirlenir. Vergi kaçakçılık suçunda eylemi gerçekleştiren gerçek kişi cezanın muhatabı olacaktır. Çünkü ceza hukukunda şahsilik ilkesi gereğince fail, işlediği fiilden dolayı cezanın muhatabı olmaktadır (Mutluer ve Kuzeyli, 2019: 226). Ayrıca cezanın şahsiliğine kaynaklık eden Anayasa ve TCK hükümleri mevcuttur. Bu kapsamda Anayasa m. 38' de "Ceza sorumluluğu şahsidir." ifadesi yer almaktadır. Buna ek olarak TCK m. 20'de ise "Ceza sorumluluğu şahsidir. Kimse başkasının fiilinden dolayı sorumlu tutulamaz." hükmü bulunmaktadır. Dolayısıyla, vergi kaçakçılık suçunda cezanın faili VUK m. 359'da yer alan hareket tiplerini ihlal eden kişidir.

Yasa koyucu kaçakçılık suçu faili için genel bir kavram kullanmamış, ancak işlenmiş fiilden hareketle suç failini belirlemeye çalışmıştır (Bayraklı, 2019: 10). Dolayısıyla VUK m. 359'da belirtilen fiilleri ihlal eden kişiler kaçakçılık suçunun failidir. Ayrıca, yasa koyucu failin kimler olabileceğini de belirtmemiştir. Nitekim, başta vergi mükellefi ve sorumlusu olmak üzere bunlarla hukuki ilişkide bulunan üçüncü kişiler suçun faili olabilmektedirler. Vergi kaçakçılık suçlarında yasadan doğan temsilci kapsamında mükellef adına hareket eden kanuni temsilci yani; veli, vasi ve kayyım da fail olabilmektedir (Karaarslan, 2006: 121 (Naklen); Hatipoğlu ve Parlar, 2005: 252).

\section{Vergi Kaçakçılık Suçlarının Takibi}

Vergi suçları, savcılık yoluyla soruşturması ve mahkemeler kanalıyla kovuşturması yapılan suçlardır. Vergi suçlarında görevli ve yetkili mahkemeler adli mahkemeler olduğundan dolayı VUK ile TCK'da kabul edilmiş ilkeler ile yargılama yapılmaktadır (Arslaner, 2017: 84). Ayrıca, VUK m. 359'da yer alan hükümleri ihlal edenler Ceza Muhakemesi Kanunu'na (CMK) tabi olarak yargılanacaklardır. Bu bakımdan ceza yargılamasında CMK'nın öngördüğünden başka sistem ve usul yoktur (Donay, 2008: 13).

Ceza iddiası, ceza davasının temelini oluşturmakla birlikte devletin cezalandırma hakkından doğmaktadır. Vergi kaçakçııık suçunda ceza iddiasını yargılama aşamasına geçirmek için yasa 
Çiftçi, T. E. (2021). Vergi kaçakçılık suçlarında soruşturma evresi.

Fiscaoeconomia, 5(2), 630-651 doi: 10.25295/fsecon.873942

koyucu bildirim ve mütalaa şartı koymuştur. Bu ceza iddiasının yargı organı tarafından araştırılması süreci soruşturma aşamasını oluşturmaktadır (Şenyüz, 2012: 406).

Ceza soruşturması, Cumhuriyet savcılarının suç fiilini öğrendikleri evreden iddianamenin mahkemece kabulüne kadar geçen süreyi kapsamaktadır (Donay, 2008: 117). CMK m. 2 soruşturmayı, kanun tarafından belirlenmiş yetkili mercilerce suç şüphesinin öğrenilmesinden iddianamenin kabulüne kadar geçen süre olarak tanımlamaktadır. Vergi kaçakçılı̆ı suçlarında soruşturma evresi için VUK'nda özel bir düzenleme söz konusudur.

Vergi kaçakçılık suçlarının takip süreci, VUK m. 367 gereğince vergi inceleme yetkisine sahip olan kişilerin ${ }^{4}$ katılımıyla başlatılmaktadır. Vergi inceleme yetkisine sahip olan kişilere aynı madde uyarınca bazı yetkiler verilmiştir. Ayrıca vergi incelemesi yapmaya yetkili kişiler VUK $\mathrm{m}$. 367 'de vergi müfettişleri ve vergi müfettiş yardımcıları ve vergi incelemesine yetkili diğer memurlar olarak belirtilmiştir. Bu kapsamda, VUK m. 359'da yazılı suç gerektiren eylemlerin gerçekleştirilmesi ile vergi incelemesine yetkili olan kişiler rapor değerlendirme komisyonlarının mütalaasıyla vergi müfettişleri ve vergi müfettiş yardımcıları doğrudan doğruya veya vergi incelemesine yetkili diğer memurlar vergi dairesi başkanlığı veya defterdarlık tarafından durumun Cumhuriyet başsavcılığına bildirilmesi gerekmektedir.

\subsection{Vergi Kaçakçılığı Suçuna İlişkin Fiilin Öğrenilmesi}

Ceza Muhakemesi Kanunu m. 160/1'de Cumhuriyet savcısının hazırlık soruşturmasındaki rolü belirlenmiştir. Bu hüküm gereğince, Cumhuriyet savcısının suç fiilini öğrenmesiyle birlikte kamu davasının açılıp açılmamasına yönelik karar vermek için hemen işin gerçeğini araştırmaya başlar. Ancak vergi kaçakçılık suçlarında soruşturma aşamasına ilişkin VUK m. 367 özel bir düzenleme getirmiştir. Buna göre, vergi kaçakçılığı suçunda savcının suç fiilini öğrenmesi VUK m. 367'de belirtilen haller ile sağlanmaktadır. Bu kapsamda Cumhuriyet savcısı suç fiilini belli makamların suç duyurusunda bulunmaları ile öğrenmekle birlikte herhangi bir nedenle kendisi de öğrenmiş olabilir. Cumhuriyet savcısının suç fiilini öğrendikten sonra araştırma yaparken delil toplayabilir, keşif yapabilir ve bilirkişi incelemesi yaptırabilir (Şenyüz, 2012: 411).

Türk Ceza Kanunu m 278/1'de suç fiilinin öğrenilmesiyle birlikte yetkili makamların bilgilendirilmesi gerektiği belirtilmiş ve bu yükümlülüğe uymayanlara bir yıla kadar hapis cezası verileceği hükme bağlanmıştır. Bu kanun hükmünde ifade edilen yetkili makamlar CMK m. 158/1'de belirtilmiştir. CMK m. 158/1 fıkrası uyarınca, Cumhuriyet başsavcılığı veya kolluk makamları suça ilişkin bilgilendirme (ihbar veya şikayet) yapılacak olan yetkili makamlardır. Nitekim vergi kaçakçılık suçlarında Cumhuriyet başsavcılığınca bilgilendirmeye ilişkin VUK 367'de özel düzenleme vardır. VUK m. 367'ye göre, vergi kaçakçılık suçunun fiilini Cumhuriyet başsavcılığının öğrenebilmesinin üç farklı yolu söz konusudur. İlk olarak vergi incelemesine yetkili olan kişiler tarafından tespit edilen kaçakçılık fiilleri Cumhuriyet başsavcılığına vergi incelemesine yetkili olan kişilerden Vergi Müfettişleri ve Vergi Müfettiş Yardımcıları yoluyla bilgilendirilir. Cumhuriyet başsavcılığının vergi kaçakçılık suçu fiillerini öğrenmenin diğer bir yolu, vergi incelemesine yetkili diğer memurlar tarafından tespitin yapılmasına bağlıdır.

\footnotetext{
${ }^{4}$ Vergi incelemesine yetkili olan kişiler VUK m. 135'e göre; vergi müfettişleri, vergi müfettiş yardımcıları, ilin en büyük mal memuru veya vergi dairesi müdürleri, Gelir İdaresi Başkanlığının merkez ve taşra teşkilatında müdür kadrolarında görev yapanlardır.
} 
Çiftçi, T. E. (2021). Vergi kaçakçılık suçlarında soruşturma evresi.

Fiscaoeconomia, 5(2), 630-651 doi: 10.25295/fsecon.873942

Üçüncü olarak, vergi incelemeye yetkili olanlar dışında VUK m. 359'a aykırılık teşkil eden eylemlerin Cumhuriyet başsavcılığınca öğrenilmesi haline ilişkin bir düzenleme VUK m. 367/2 fıkrasında yer bulmaktadır. Vergi kaçakçılık suçunun savcılık tarafından ihbar, şikayet, basın ya da diğer yollarla öğrenilmesi halinde VUK m. 367/2 fıkrası devreye girecektir (Sarıcaoğlu, 2018: 134). VUK m. 367/2 hükmü uyarınca, vergi kaçakçılık suçunu diğer şekilde öğrenen Cumhuriyet başsavcılığı hemen ilgili vergi dairesini bilgilendirerek inceleme yapılmasını istemesi gerekmektedir. Bu durumda, savcıların dava açabilmesi için ilgili vergi dairesinden görüşün ${ }^{5}$ alınması gerekmektedir (Şenyüz, 2016: 29). Nitekim vergi kaçakçılık suçunun ihbar, şikayet ya da iddia yoluyla öğrenen Cumhuriyet başsavcılığının kolluğa ihtiyacı vardır. Cumhuriyet başsavcılığı, bu kolluk ihtiyacını vergi idaresine başvurarak bilgilendirme ve inceleme yapılması yoluyla karşılamaktadır. Dolayısıyla VUK m. 267/2 hükmü, vergi kaçakçılık suçunun soruşturulmasında vergi idaresini kolluk olarak görevlendirmiştir (Candan, 2019: 413).

Verginin doğruluğunu tespite ilişkin faaliyetler vergi denetim aracı olan vergi incelemesi yoluyla sağlanmaktadır. Vergi Denetim Kurulu Yönetmeliği (VDKY) m. 57/1'e göre, Vergi Usul Kanunu ve diğer gelir kanunlarına göre yapılan vergi incelemeleri sonucunda vergi inceleme raporu düzenlenir. Vergi inceleme sürecinin sonunda düzenlenen rapor, denetim ve inceleme aşamalarının ve varılan sonuçların sistemli ve düzenli bir şekilde aktarıldığı vergi inceleme elemanın kanaatini ve önermelerini yansıtan bir metindir (Yüce, 2018: 237). Vergi inceleme raporunun ekini oluşturan vergi tekniği raporu, Vergi Denetim Kurulu Yönetmeliği (VDKY) m. $57 / 3$ uyarınca "Yürütülmekte olan incelemelerde birden fazla mükellefi veya vergi türünü ya da aynı mükellefin birden fazla vergilendirme dönemini kapsayan eleştiri konusu yapılabilecek hususların tespit edilmesi halinde, konunun tek bir raporda ifade edilebilmesi amacıyla" düzenlenebilir. Ayrıca VDKY m. 58/1 gereğince VUK m. 359'da yer alan kaçakçılık suç fiillerinin tespiti halinde vergi suçu raporu düzenlenir. Vergi suçu raporu, savcılığın vergi kaçakçılık suç fiilini öğrenmesine yönelik suç duyurusu niteliği taşır (Şenyüz, 2016: 22). Vergi suçu raporları, mükellefe ilişkin bilgiler verildiği ve suç fiillerinin belirtilerek ihlal edilen yasa hükümleri gösterilmek suretiyle vergi incelemesine yetkili olan kişiler tarafından hazırlanan bir belgedir (Keskin ve Suçiçek, 2016: 54 (Naklen); Erdem, 2011: 109-110). Dolayısıyla kişinin kaçakçılık suçu işleyip işlemediğinin tespiti ve bu suç fiilinin tespiti halinde düzenlenmesi gerekli raporlar vergi incelemesine yetkili olan kişiler tarafından gerçekleştirilmektedir. Vergi incelemesine yetkili kişiler, revizyon ve muhasebe konularında yetişmiş, bu konularda teknik bilgiye sahip olan kişilerdir (Baykara, 2009: 405).

Yargıtay Ceza Kurulu'nun 16.12.2001 gün ve 11-212/219 sayılı kararında; kaçakçılık suçunun oluşup oluşmamasında manevi unsurun varlığının tespitinin ceza mahkemelerince yapılması gerekmektedir. Bu karar, vergi inceleme elemanlarına vergi incelemesi sırasında tespit ettikleri kaçakçılık suçuna ilişkin manevi unsurun varlığının araştırılması neticesinde Cumhuriyet savcılığına bildirilip bildirilmeme hususunda yetki tanımamıştır. Vergi inceleme elemanları, tespit ettikleri kaçakçılık suçlarının varlığını, maddi unsurların eylemlerine bakarak belirlemek ve bu eylemleri Cumhuriyet savcılığına bildirmek zorundadırlar (Candan, 2019: 411 (Naklen); Ok ve Gündel, 2002: 248). Ancak, 18.06.2002 tarih ve 306 sayılı VUK Genel Tebliğ'inde, sahte veya muhteviyatı itibariyle yanıltıcı belgenin kullanımı ile kaçakçılık suçunun oluşumunda kastın bulunup bulunmadığının vergi incelemesine yetkili kişiler tarafından değerlendirilip

\footnotetext{
${ }^{5}$ Ayrıntılı bilgi için bkz; Şenyüz, 2016: 28-33.
} 
Çiftçi, T. E. (2021). Vergi kaçakçılık suçlarında soruşturma evresi.

Fiscaoeconomia, 5(2), 630-651 doi: 10.25295/fsecon.873942

\begin{abstract}
kastın varlığı tespit edilirse vergi suçu raporunun düzenlenmesi ve Cumhuriyet savcılıklarına suç duyurusunda bulunulması gerektiği belirtilmektedir. Dolayısıyla, vergi incelemesine yetkili olan kişilerce sahte veya muhteviyatı itibariyle yanıltıcı belgenin kullanımında kastın bulunmadığının tespitinde vergi suçu raporu düzenlenmeyecek ve Cumhuriyet savcılıklarına suç duyurusunda bulunulmayacaktır. Bu tebliğ içeriğine göre, vergi incelemesine yetkili olanlara yargı erkinin ve bu erkin içinde bağımsız mahkemelerin yetkisine giren bir konuda değerlendirme ve yorum yapma yetkisi verdiği görülmektedir. Bu durum tebliğin amacını aşmakla birlikte hukuka aykırılık oluşturmaktadır (Çavuş, 2016: 174-175).
\end{abstract}

\title{
4.2. Vergi Kaçakçılığı Suçuna İlişkin Bildirim Zorunluluğu
}

Vergi Usul Kanunu m. 359'da yer alan kaçakçılık suçlarına ilişkin kuralların ihlali vergi incelemesi sırasında vergi incelemesine yetkili olanlar tarafından tespit edilmesi halinde Cumhuriyet savcılı̆ına farklı usullerle bildirim mecburiyeti getirilmiştir. Vergi incelemeye yetkili olan kişilere bu bildirim mecburiyeti adli bir görev olarak verilmiştir (Şenyüz, 2012: 412). Ayrıca, VUK'ta yetkili Cumhuriyet savcılığının kim olduğu belirtilmediğinden vergi kaçakçılık suçları için dava açılacak mahkeme nezdindeki Cumhuriyet savcılığını olarak anlamak gerekir (Yüce, 2018: 236).

Vergi Usul Kanunu m. 367/1 gereğince, vergi kaçakçılık suçunu ve failini tespit eden vergi incelemesine yetkili olanların bildirimde bulunmaları bir zorunluluktur. Dolayısıyla yasa koyucu bu durumda vergi inceleme elemanlarına takdir yetkisi vermemiş, bildirimde bulunma zorunluluğu getirmiştir (Candan, 2019: 410). Görüldüğü üzere yasa koyucu kaçakçılık suçlarında dava sürecinin başlaması için vergi idaresine bildirimde bulunma zorunluluğu getirmiştir. Cumhuriyet başsavcılığına bildirim zorunluluğu dışında vergi idaresinin inisiyatifi bulunmamaktadır (Akkaya, 2000: 87).

Bildirim mecburiyeti, vergi incelemesine yetkili olanlar açısından VUK m. 367/1'e göre farklı usullere bağlanmıştır. VUK m. 367/1'e göre vergi incelemesi sırasında vergi kaçakçılık suçuna yönelik eylemlerin Vergi Müfettişleri ve Vergi Müfettiş Yardımcıları tarafından tespit edilmesi halinde rapor değerlendirme komisyonunun mütalaasıyla doğrudan doğruya Cumhuriyet başsavcılığına bildirme mecburiyeti getirilmiştir. Ayrıca, VUK m. 367/1 uyarınca, vergi incelemesine yetkili diğer memurlar tarafından vergi kaçakçılık suçuna yönelik eylemlerin tespiti halinde rapor değerlendirme komisyonunun mütalaasıyla doğrudan doğruya savcılığa bildiremezler. Vergi incelemesine yetkili diğer kişiler, öncelikle kaçakçılık suçu raporunu bağlı oldukları vergi dairesi başkanlığı veya defterdarlığa ileteceklerdir. Daha sonra, vergi dairesi başkanlığı veya defterdarlık tarafından kaçakçılık suçu raporu mütalaa verilmesi talebiyle rapor değerlendirme komisyonuna gönderilir. Bu makamlar tarafından hazırlanan mütalaa ile birlikte kaçakçılık suçu raporu Cumhuriyet başsavcılığına bildirilir (Şenyüz, 2016: 24).

VUK m. 367/1 gereğince vergi incelemesi sırasında kaçakçılık suçlarının tespiti halinde Vergi Müfettişleri ve Vergi Müfettiş Yardımcılarının doğrudan doğruya savcılığa bildirim mecburiyetleri söz konusuyken vergi incelemesine yetkili diğer memurlar için, vergi dairesi başkanlığı veya defterdarlık aracılığıyla savcılığa bildirim zorunluluğu getirilmiştir. Burada ortaya çıkan farklı bildirim usulünün vergi müfettiş ve yardımcılarının geçirdikleri mesleki süreç ve merkezde olmalarının etkili olduğu anlaşılmaktadır (Şenyüz, 2012: 413). 
Çiftçi, T. E. (2021). Vergi kaçakçılık suçlarında soruşturma evresi.

Fiscaoeconomia, 5(2), 630-651 doi: 10.25295/fsecon.873942

Kanunda, mütalaanın alınması koşul olmakla birlikte olumlu olması zorunlu değildir. Rapor değerlendirme komisyonunun vergi kaçakçılık suç fiiline olumsuz mütalaa vermesi, Cumhuriyet savcılığına suç duyurusunda bulunmayı engellememekle birlikte olumsuz mütalaa ile de başvuru yapılabilir (Ağar, 2016: 341).

\subsection{Kovuşturmanın Yapılabilmesi için Gereken Mütalaa Şartı}

Vergi kaçakçılık suçlarının tespit edilmesi ve cezalandırılması ceza mahkemelerinin görev alanına girmekte ise de, VUK m. 367 uyarınca vergi suçundan zarar gören vergi idaresinin “mütalaa”sı yargılama şartı olarak tezahür etmektedir (Kırmaz, 2015: 330).

Yargıtay Ceza Genel Kurulu bir kararında (YK., CGK., E. 2012/1512 K. 2014/366 T. 11.7.2014), ceza hukukunda "mütalaa" yı suç fiili dolayısıyla hak ve menfaatleri ihlal edilen kurumun kovuşturmanın yapılabilmesi için vereceği yazılı görüş olarak ifade etmiştir. Ayrıca ilgili kararda VUK m. 367'de düzenlenen vergi kaçakçılık suçları için mütalaanın muhakeme şartı olduğu vurgulanmıştır.

Vergi Usul Kanunu m. 367/1'e göre, kaçakçılık suçunun tespiti halinde vergi idaresi tarafından savcılığa mütalaa yoluyla bildirilmesi gereklidir. Bu bakımdan vergi kaçakçılık suçlarında kovuşturmanın bir şartı olarak mütalaa VUK 367/1'de düzenlenmiştir. Vergi idaresi tarafından mütalaa şartının yerine getirilmemesi nedeniyle muhakeme aşamasına geçilmesine engel teşkil etmektedir. Bir bakıma mütalaa aracılığıyla vergi kaçakçılık suçunun yargılama aşamasına geçilmesinde vergi idaresinin katılımı gerekli kılınmıştır. Vergi kaçakçılık suçunun soruşturma aşamasında vergi idaresinin mütalaa şartı ile katılımı, uyuşmazlığı çözen yargı organı için maddi gerçeğe ulaşma bakımından yol gösterici olacaktır (Sarıcaoğlu, 2018: 237).

Vergi Usul Kanunu m. 367/1 uyarınca, vergi incelemesi neticesinde vergi kaçakçılık suçu fiili ve faili ile ilgili Cumhuriyet başsavcılığına suç duyurusu hakkında mütalaa verilmektedir. Mütalaayı vermekle yükümlü olanlar VUK m. 367/1'de belirtilmiştir. Bu hükme göre, vergi incelemesi Vergi Müfettişleri ve Vergi Müfettiş Yardımcıları tarafından gerçekleştirilmişse ilgili raporun değerlendirme komisyonunun mütalaasıyla doğrudan doğruya Cumhuriyet başsavcılığına bildirilmesi gerekmektedir. Buna ek olarak vergi incelemesine yetkili olan diğer memurlar tarafından vergi kaçakçılık suçu tespit edilmişse, ilgili rapor değerlendirme komisyonunun mütalaasıyla vergi dairesi başkanlığı veya defterdarlık tarafından bildirilmektedir.

Vergi kaçakçılık suçlarının tespitinde Cumhuriyet başsavcılığa bildirim şartını oluşturan mütalaanın nedeni, vergi incelemesine yetkili olan kişilerce her fırsatta ve olur olmaz iddialarla Cumhuriyet savcılıklarına ve ceza mahkemelerine şüpheli ya da sanık sıfatıyla çıkan mükelleflerin ekonomik ve ticari hayatları üzerindeki olumsuz etkilerin engellenmesidir. Yasa koyucu mütalaa şartını, vergi idaresinin idari ve siyasi baskı ve tehdit aracı olarak kullanım ihtimaline karşılık mükelleflere bir güvence sağlamak amacıyla düzenlemiştir (Candan, 2019: 412). Ayrıca, verginin teknik bir konu olması dolayısıyla vergi suçlarının tespitinde uzmanlık ve bilgi gerektirmektedir. Kaçakçılık suçlarının soruşturma ve kovuşturmanın uzman ve yetkili kişilerin mütalaa şartına bağlanması, vergi tekniği hususunda yeterince uzmanlığı bulunmayan soruşturma ve kovuşturma makamlarının kanuna ve hukuka uygun karar vermelerine yardımcı olur (Çavuş, 2016: 170). Ancak idareye bu şekilde tanınan yargılama koşulu, yürütme organının ceza soruşturma ve kovuşturmasını durdurma yetkisi ortaya çıkmaktadır. (Donay, 2008: 71). 
Çiftçi, T. E. (2021). Vergi kaçakçılık suçlarında soruşturma evresi.

Fiscaoeconomia, 5(2), 630-651 doi: 10.25295/fsecon.873942

Anayasa'nın m. 138'de yargının, hiçbir organ ve makamdan emir ve talimat almayacağı, yargıya tavsiye ve telkinde bulunulamayacağı belirtilmiştir. Nitekim, Anayasa Mahkemesinin bir kararında (Anayasa Mahkemesi GK, E. 2009/89 K. 2011/40 T. 10.2.2011), muhakeme şartı olarak mütalaanın VUK $\mathrm{m}$. 367'de düzenlenmesi, vergi idaresi tarafından siyasi olarak kullanılabileceğine yönelik hukuk devletine aykırılık teşkil ettiği, ayrıca mütalaanın yargı organlarına müdahale anlamına geleceği gerekçesiyle yargı bağımsızlığı ile çelişeceği için Anayasa'nın 2., 11. ve 138. maddelerine aykırı olduğu ileri sürülmüştür. Aynı Anayasa Mahkemesi kararında, "Vergi kaçakçılığı suçu kapsamına giren eylemlerin bulunup bulunmadığına ilişkin özel ve teknik bilginin yer aldığı bu mütalaalar, koğuşturma aşamasında değerlendirilebilecek takdiri delil niteliğinde olduğundan hakimlere emir ve talimat verme, telkin ve tavsiyede bulunma olarak değerlendirilemez." ifadesi yer almaktadır.

Rapor Değerlendirme Komisyonu'nun mütalaası ile vergi incelemesine yetkili olan kişilerin kaçakçılık suçunun tespitinde verilen kararın doğruluğu bir bakıma onaylanmış olur. Rapor değerlendirme komisyonları vergi kaçakçılık suçuna ilişkin fiile yönelik düzenlenen raporları mevzuata uygun olup olmadığının değerlendirmesini yapmakla birlikte usul hatası ve maddi hata yönünden de raporları inceler (RDKY., m. 8/1). Yasa koyucu tarafından düzenlenen mütalaa ve görüş şartı, doğrudan yargılama aşamasına geçilmesine getirilen bir sınırlamadır. Bu sınırlama, ortaya çıkabilecek sorunların önlemesine yöneliktir. Bu bakımdan mütalaa, vergi incelemesine yetkili olan kişilerin mükellefle şahsi ilişkilerinde kaynaklı sorunlara bağlı olarak yapılan değerlendirmeleri önlemesine yönelik mükellefler için bir güvence sağlayabilmektedir (Şenyüz, 2016: 19). Nitekim, mütalaanın verilmiş olması Cumhuriyet savcısı tarafından mutlaka dava açılacağı anlamına da gelmeyecektir. Dava şartı olan mütalaanın, Cumhuriyet savcısının alacağı kararlarda bağlayıcılığı söz konusu değildir (Ağar, 2016: 339-341). Bu kapsamda vergi incelemesine yetkili olan kişilerce verilebilecek yanlış bir karar, ceza muhatabını suç şüphelisi konumunda adli makamlar önüne çıkarabilecek kadar ağır bir karardır. Bu durumda her ne kadar Cumhuriyet savcılığı tarafından delil toplamak için yapılacak araştırmalar söz konusu olsa da, vergi denetim raporları savcılık için önemli bir delil niteliğindedir. Dolayısıyla mütalaa, ceza muhatabı açısından bir güvence sağlamakla birlikte savcılığın hazırlayacağı iddianame için yol gösterici nitelikte bir görüş yazısıdır.

Şenyüz (2016), mütalaanın idari işlem özelliği olması nedeniyle idarenin her türlü eylem ve işlemlerine karşı yargı denetimini sağlayan Anayasa'nın 125. maddesi, hukuk devleti, yargı bağımsızlığı ve adil yargılama ilkesine ters düştüğünü öne sürmektedir. Ayrıca, ceza muhatabı aleyhine düzenlenen mütalaaya karşı itiraza uygun mekanizmanın getirilmesi mükellef hakları açısından önemli bir adım olacağı görüşündedir (Şenyüz, 2016: 21).

Donay (2008), yargı oranının görevinin başladığı yerde yürütme organına bu şekilde yetki tanınması yargı bağımsızlığına ve eşitlik ilkesine aykırı düşeceği görüşündedir. Bu kapsamda Donay, VUK'a aykırı bir suçun meydana gelmesi halinde Cumhuriyet savcılığı gerek gördüğünde vergi idaresinden görüş isteyebileceği şeklinde öneri getirmiştir (Donay, 2008: 71).

Şentürk (2019), mütalaanın soruşturma başlatmasına ve kişiyi şüpheli haline gelmesine neden olan bir idari işlem olarak belirtmiştir. Ayrıca Şentürk, mütalaanın idari işlem olmasından dolayı soruşturma aşamasında idari yargı denetimine tabi tutulması gerektiğini ve bunun da hukuk devleti ilkesinin gereğinden kaynaklandığını öne sürmektedir (Şentürk, 2019: 5). 
Çiftçi, T. E. (2021). Vergi kaçakçılık suçlarında soruşturma evresi.

Fiscaoeconomia, 5(2), 630-651 doi: 10.25295/fsecon.873942

\begin{abstract}
Ağar (2016), mütalaanın kanunda vatandaşın ekonomik ve mali güvenliği amacıyla yer almakta ise de diğer tüm özel soruşturma usullerinde olduğu gibi, Cumhuriyet savcısının soruşturma yapma ve dava açma tekeline aykırı olduğu görüşündedir (Ağar, 2016: 343).
\end{abstract}

Bayraklı (2020), vergi inceleme elemanı tarafından tespit edilen kaçakçılık suç fiiline ilişkin rapor değerlendirme kurulu tarafından olumlu mütalaanın alınması zorunluluğunu, Cumhuriyet başsavcılığına müracaatının önünde bir engel olarak nitelendirmiştir. Ayrıca Bayraklı, diğer inceleme elemanları tarafından tespit edilen suç fiiline yönelik Cumhuriyet başsavcılığına müracaatta ikinci bir engelin oluştuğunu belirtmektedir. Bu bakımdan, diğer vergi inceleme elemanlarının doğrudan doğruya Cumhuriyet başsavcılığına müracaat edemeyeceklerinden dolayı, bu müracaatın vergi dairesi başkanı veya defterdar aracılığıyla yapılması gerekmektedir. Dolayısıyla defterdar veya vergi dairesi başkanı olumlu görürse Cumhuriyet başsavcılığına müracaat edecektir. Bayraklı, bu yaklaşımın kendi içinde çelişkiler barındırdığını ifade ederek, defterdarın hem inceleme yetkisinin bulunmasının hem de olumlu görüş bildiren konumunda olmasının böyle bir durumun ortaya çıkmasına neden olduğunu ileri sürmektedir (Bayraklı, 2020: 203-204).

Öztürk ve Yavaşlar (2020), çalışmasında VUK m. 367'de düzenlenen mütalaanın vergi idaresinden ve Yürütme Organından tamamen bağımsız kuruluşlarla güvence sağlayabileceği ileri sürülmüştür. Mevcut sistemde bu özelliklere sahip kuruluşlar ise, mensupları yüksek hâkim ve hâkim statüsünde olan, Danıştay'ın idari işlerle görevli, Birinci Dairesi ile İdari İşler Kurulu ve, idari görevleri de olan, bölge idare mahkemeleri olarak belirtmiştir. Ayrıca, bu kuruluşlar 4483 sayılı Memur ve Diğer Kamu Görevlilerinin Yargılanması Hakkında Kanun uyarınca benzeri görevi yürüttüklerinden dolayı yeterince deneyime sahip olduğu görüşündedirler. Bu kapsamda vergi kaçakçılık suç fiillerine yönelik ceza davasının açılması koşulu, bölge idare mahkemesi nezdinde kurulacak özel yetkili dairenin kararına bağı ılması gerektiği ifade edilmiştir (Öztürk ve Yavaşlar, 2020: 172).

Vergi kaçakçılık suçunda soruşturma ve kovuşturma şartı olarak mütalaa veya görüş kapsamında idareye verilen yetkinin varlığı söz konusudur. Dava şartı olarak mütalaa ve görüş bildirimi idari makamlar tarafından gerçekleştirilen idari bir işlemdir. VUK m. 367 düzenlemesinde, vergi kaçakçılık suçları için Cumhuriyet savcılığı tarafından kamu davasının açılması idari makamların iznine bağlı olduğu anlamı çıkarılabilmektedir. Bu durumda, idari makamların yargı erkine müdahalesi şeklinde oluşan algı, ceza muhatabının yargı bağımsızlığına olan güvenini zedeleyebilmektedir.

Vergi Usul Kanunu m. 140'ta, vergi müfettişleri ile vergi müfettiş yardımcıları tarafından düzenlenen vergi inceleme raporları için rapor değerlendirme komisyonlarının kimlerden oluştuğu ve bu komisyonların görevleri düzenlenmiştir. Bu kanun hükmü gereğince, vergi müfettişleri ile vergi müfettiş yardımcıları tarafından düzenlenen vergi inceleme raporları için rapor değerlendirme komisyonları, meslekte on yılını tamamlamış en az üç vergi müfettişinden oluşturulacaktır. Ayrıca bu komisyonlar, vergi müfettişleri ile vergi müfettiş yardımcıları tarafından düzenlenen vergi inceleme raporlarını vergi kanunları ile bunlara ilişkin kararname, tüzük, yönetmelik, genel tebliğ, sirküler ve özelgelere uygunluğu yönünden değerlendirir. Buna ek olarak "Rapor Değerlendirme Komisyonlarının Oluşturulması ile Çalışma Usul ve Esasları Hakkında Yönetmelik (RDKY)" m. 8/1 gereğince, rapor değerlendirme komisyonları vergi inceleme raporlarını maddi hata ve usul hatası içerip içermediği yönünden de 
Çiftçi, T. E. (2021). Vergi kaçakçılık suçlarında soruşturma evresi.

Fiscaoeconomia, 5(2), 630-651 doi: 10.25295/fsecon.873942

değerlendirir. Aynı yönetmeliğin 8/2 maddesine göre, kaçakçılık suçlarına yönelik fiillerin işlenmesi dolayısıyla oluşturulan vergi suçu raporlarına ilişkin rapor değerlendirme komisyonlarının mütalaa vermesi gerektiği düzenlenmiştir.

Vergi Usul Kanunu m. 140 hükmü uyarınca, vergi incelemesi yapmaya yetkili diğer kişiler tarafından oluşturulan vergi inceleme raporları, Gelir İdaresi Başkanlığı merkez ve taşra birimlerinde oluşturulacak rapor değerlendirme komisyonları tarafından değerlendirileceği belirtilmiştir. Vergi incelemesi yapmaya yetkili diğer kişiler tarafından oluşturulan vergi inceleme raporlarını, vergi dairesi başkanlıkları ve defterdarlıklar bünyesinde kurulan rapor değerlendirme komisyonları vergi kanunları ile bunlara ilişkin kararname, tüzük, yönetmelik, genel tebliğ, sirküler ve özelgelere uygunluğu ile maddi hata ve usul hatası içerip içermediği yönünden değerlendirir (RDKY., m. 5/1, m. 5/2, m. 8/1). Ayrıca, vergi incelemesi yapmaya yetkili diğer kişiler tarafından kaçakçılık fiillerinin tespiti halinde rapor değerlendirme komisyonları vergi suçu raporlarına ilişkin mütalaa verirler (RDKY., m. 8/1).

Vergi incelemesine yetkili kişilerce kaçakçılık fiilin tespit edilmesi halinde Cumhuriyet başsavcılıklarına bildirim için rapor değerlendirme komisyonlarının mütalaası şart olarak düzenlenmiştir. Buna göre Candan (2019), mütalaa şartına ilişkin olarak; “incelemeyi yapan vergi müfettişinin veya müfettiş yardımcısının raporunu değerlendirerek, uygun gören komisyonla mütalaayı veren komisyon aynı komisyondur." şeklinde görüşünü ifade etmiştir. Dolayısıyla, vergi inceleme raporunu uygun gören komisyonun görüşü ortaya çıkmış ve tarafı belli olmuştur. Candan, tarafı belli olan komisyonun tarafsız bir şekilde raporu tekrar değerlendirmesi ve mütalaa istenmesinin yararının ne olacağı üzerinde düşünülmesi gereken bir konu olduğunu ifade etmektedir (Candan, 2019: 414).

\subsection{Kamu Davasının Açılması}

Vergi kaçakçılık suç fiiline ve failine yönelik davanın asliye ceza mahkemesinin önüne gelebilmesi için gerekli soruşturma aşamasının tamamlanması gerekmektedir. Soruşturma aşaması, mahkemede davanın görülmesine gerek olup olmadığını araştırmaya yönelik bir aşamadır.

Vergi Usul Kanunu m. 367, vergi kaçakçılık suçlarında kovuşturma şartı olarak mütalaa veya görüş alınması öngörülmüştür. Bu kanun hükmü vergi kaçakçılık suçları için kamu davasının açılmasına savcının takdiri dışında bir sınırlama getirmiştir. Bu bakımdan Cumhuriyet başsavcılığı mütalaa veya görüş alınmadan yeterli suç şüphesinin varlığına kanaat etse bile bu dava şartı sağlanana kadar iddianame düzenleyemez ve dava açamaz (Şenyüz, 2016: 16). Ancak bu dava şartlarının sağlanmasıyla Cumhuriyet savcılığı, yaptığı araştırmalar neticesinde delilleri toplar ve yeterli delile ulaşırsa kamu davası açar (Taştan, 2013: 42).

Vergi kaçakçılığı suçları için vergi incelemesine yetkili olan kişilerce Cumhuriyet başsavcılığına dava şartı olan mütalaanın verilmesi kamu davasının açılmasını zorunlu kılmamaktadır. Bu kapsamda mütalaanın dava şartı olması, mutlaka kamu davasının açılacağı anlamına gelmemektedir (Yüce, 2018: 240). Nitekim mütalaanın dava şartı olması ve Cumhuriyet savcısının da mütalaaya bağlı olarak dava açmasının gerekliliği, Anayasa'nın 138. maddesinde düzenlenen yargı bağımsızlığına, yargının hiç bir makamdan emir, talimat ve tavsiye almayacağı ve yargı erkine telkinde bulunulmayacağı temel ilkesine de aykırılık teşkil edecektir. 
Çiftçi, T. E. (2021). Vergi kaçakçılık suçlarında soruşturma evresi.

Fiscaoeconomia, 5(2), 630-651 doi: 10.25295/fsecon.873942

Ceza davaları kural olarak kamu adına açılacağı için davayı taraflar değil Cumhuriyet savcısı açar ve yürütür (Yüce, 2018: 232). Nitekim, CMK m. 170/1'de kamu davası açma görevi Cumhuriyet savcısına verilmiştir. Savcı tarafından kamu davasının açılmaması durumunda mahkeme kendiliğinden harekete geçemez (Şenyüz, 2012: 407). Davanın duruşmaya hazır olabilmesi için Cumhuriyet savcılığı tarafından iddianamenin düzenlenmiş ve mahkemece kabul edilmiş olması gerekir. CMK 175/1'e göre mahkemenin iddianamenin kabulü ile kamu davası açılmış olur. Dolayısıyla bu aşamada kovuşturma evresi de başlamıştır.

Ceza Muhakemesi Kanunu m. 160'a göre, Cumhuriyet savcısı bir suçun işlendiği izlenimi veren bir hal meydana geldiğinde ve bu durumu ihbar ya da diğer yollarla öğrenirse hemen işin gerçeğini araştırmak için harekete geçer. Aynı madde hükmüne göre, Cumhuriyet savcısı maddi gerçeğin araştırılması ve adil yargılama için deliller toplar. CMK m. 161/1 uyarınca, Cumhuriyet savcısı doğrudan doğruya veya adli kolluk görevlileri aracılığıyla her türlü araştırmayı yapar (Yüce, 2018: 233). Cumhuriyet savcısının bu araştırma faaliyeti kamu davasının açılıp açılmamasına yöneliktir. Yapılan bu araştırma sonucunda kamu davasının açılmasına ya da kovuşturmaya yer olmadığına yönelik karar verebilir. Cumhuriyet savcısı soruşturma sonunda suç oluştuğuna ilişkin şüphenin varlığı halinde iddianame hazırlanır ve görevli mahkemeye sunulur. Ceza mahkemesi CMK uyarınca iddianameyi inceler ve mahkeme tarafından kabul edilirse ceza davası açılmış olur (Yüce, 2018: 233).

Cumhuriyet savcısının gerçekleştireceği soruşturma evresi neticesinde toplanan deliller, suçun işlendiği hususunda yeterli şüphe uyandırıyorsa bir iddianame düzenlenir (CMK m. 170/2). CMK m. 225/1'de mahkeme tarafından verilecek hüküm, iddianamede yer alan fiil ve fail hakkında verileceği ifade edilmektedir. Bu kapsamda, vergi kaçakçılığı suçu dolayısıyla Cumhuriyet savcısı tarafından düzenlenen iddianamede fail ile fiilin açıkça belirlenmesi ve VUK m. 367'de öngörülen yargılama şartı olan mütalaaya uygun bulunması gerekmektedir (Yüce, 2018: 250). Bununla birlikte soruşturma sonunda savcılı̆ın hazırlayacağı iddianamenin de vergi tekniği raporuna uygun olması gerekmektedir. Savcılık tarafından hazırlanan iddianamenin vergi suçu raporuna ve mütalaaya uygun olmasına yönelik olarak Yargıtay'ın bir kararında "sanık hakkında yoklama tutanağı, vergi suçu raporu ve defterdarlık mütalaasına uygunluk göstermeyen iddianame ile açılan davaya devamla hüküm kurulması.." şeklinde ifade yer almaktadır (Çavuş, 2016: 172; Yargıtay 9. C.D., 22.02.1994 T., E. 1994/34, K. 1994/920).

Vergi kaçakçılık suç fiillerinden sahte belge düzenlemek ve kullanmak ayrı ve bağımsız suçlardır. Ancak uygulamada mütalaanın hangi suça yönelik düzenlediğine dikkat edilmeden kamu davası açıldığı görülmektedir. Bu kapsamda kovuşturmada hüküm tesis edilmesi, bu kararın genel olarak bozma konusu edildiği görülmektedir (Taştan, 2013: 43).

Davasız yargılama olmaz ilkesi gereğince vergi kaçakçılık suçlarında soruşturma aşamasından sonra muhakeme evresine geçilmektedir. Vergi kaçakçıı̆ı̆ı suçlarında ceza yargılaması yapılabilmesi için muhakeme şartlarının varlığını aramaktadır. Yargıtay Ceza Genel Kurulu kararında, muhakeme şartlarının varlığı halinde muhakemenin yapılmasını zorunlu kılacağı belirtilmiştir (YK., CGK., E. 2012/1512 K. 2014/366 T. 11.7.2014). Ayrıca, CMK m. 223/8'de soruşturma ve kovuşturma şartlarının yerine getirilmemesi davanın düşme sebebi olarak ifade edilmiştir. Bu kapsamda vergi kaçakçılık suçlarında soruşturma ve kovuşturma şartı olarak yer alan mütalaanın Cumhuriyet başsavcılığına verilmemesi davanın düşme sebebidir. CMK m. 
Çiftçi, T. E. (2021). Vergi kaçakçılık suçlarında soruşturma evresi.

Fiscaoeconomia, 5(2), 630-651 doi: 10.25295/fsecon.873942

\begin{abstract}
223/8'de durma kararı da belirtilmiş olup, "soruşturmanın veya kovuşturmanın yapılması şarta bağlı tutulmuş olup da şartın henüz gerçekleşmediği anlaşılırsa; gerçekleşmesini beklemek üzere, durma kararı verilir." hükmü yer almaktadır. Aynı madde hükmü uyarınca, mütalaanın soruşturma ve kovuşturma için şarta bağlanması nedeniyle henüz gerçekleşmediği anlaşılırsa gerçekleşene kadar davada durma kararı verilecek ve bu şartın sağlanması beklenecektir. Ancak, durmanın ne kadar süreceği kanunda düzenlenmediğinden bu hususta belirsizlik vardır (Ağar, 2016: 342). Ceza yargılamasının şarta bağlanıp bağlanmaması yargılamanın her aşamasında resen araştırılacaktır (Çavuş, 2016: 170).
\end{abstract}

\title{
5. Sonuç
}

Vergiler, toplumsal intiyaçlar şeklinde ortaya çıkan kamusal hizmetlerin etkin bir şekilde finansmanını sağlamayı amaçlamaktadır. Mali ödeme gücü olan bireyler vergiler aracılığıyla kamusal hizmetlerin sunumuna finansal katkı sağlamaktadırlar. İşte bu şekilde devlet ile bireyler arasında vergilerden kaynaklı olarak bir ilişki ortaya çıkmaktadır. Vergilerin finansal kaynak olma özelliğinden dolayı eksiksiz ve zamanında tahsilat devletler için büyük önem taşımaktadır. Buna yönelik olarak da vergi ilişkisi neticesinde vergi borçlusu olan mükelleflere çeşitli ödevler yüklenmektedir. Yasa koyucu tarafından yaptırım gücü ile desteklenen bu ödevlerin mükellefler tarafından yerine getirilmesi beklenmektedir.

Mükellefler ile devlet arasında vergi ilişkisi temelinde bazı anlaşmazlıklar ortaya çıkabilmektedir. Vergi ilişkisinin temeli borç-alacak üzerinde kurulu bir oluşum içinde olmasından kaynaklı olarak kanunlarla taraflara verilen hak ve yükümlülüklerin ihlali neticesinde yaptırım öngörülmektedir. Vergi kanunlarına aykırı hareketlere uygulanacak yaptırımlar; vergi suçu ve/veya vergi kabahati cezalarıdır. Vergi kabahatleri vergi mahkemesinde, vergi suçları ise ceza mahkemelerinde yargılanmaktadır. Vergi kaçakçılık suçlarının yargılanması CMK hükümlerine göre yapılacaktır.

Vergi Usul Kanunu m. 367/1 hükmü, vergi incelemesine yetkili olan kişiler bakımından vergi kaçakçılık suçunun tespiti halinde Cumhuriyet savcılığına bildirim yükümlülüğü getirmiştir. Nitekim, bildirim yükümlülüğünün koşulu da VUK m. 367/1'de belirtilmiştir. Buna göre, vergi incelemesine yetkili olan kişiler tarafından kaçakçılık suçunun tespiti halinde Rapor Değerlendirme Komisyonu'nun mütalaası istenir. Mütalaa, VUK m. 367/1'de belirtilen kişilerce vergi kaçakçılık suçunun Cumhuriyet savcılığına bildirim şartını oluşturmaktadır.

Yargı erkinin vergi gibi teknik ve uzmanlık gerektiren bir alanda yetkinliğe sahip olması mümkün değildir. Vergi kaçakçılık suç fiil ve faillerinin gerek soruşturma gerekse de kovuşturma aşamalarında yargı erkinin karar vermesine yol gösterici olacak uzman görüşü önem arz etmektedir. Bu bakımdan vergi kaçakçılık suçlarında mütalaa veya görüş yasa koyucu tarafından dava şartı olarak VUK m. 367'de düzenlenmiştir. Mütalaa/görüş ve vergi denetim raporları vergi alanında uzmanlaşmış kişiler tarafından hazırlanan ve bildirilen belgelerdir. Mütalaanın Rapor Değerlendirme Komisyonları tarafından hazırlanmaları ve vergi denetim raporlarının da vergi incelemesine yetkili kişiler tarafından düzenlenmesi suç fiili ve faili hakkında soruşturma aşamasında Cumhuriyet savcılığının vereceği kararda yol göstericidir. Ancak, soruşturma aşamasında Cumhuriyet savcıllğı mütalaaya ve vergi denetim raporlarına bağlı değildir. Cumhuriyet savcılığı, vergi kaçakçılık suç fiiline ve failine yönelik yapılan 
araştırmalar ve elde edilen deliller çerçevesinde kamu davasının açılıp açılmamasına karar verecektir.

Vergi kaçakçııık suç fiil ve failleri hakkında soruşturma ve kovuşturma aşamasına başlanmasını idari işlem olan mütalaa ve görüş şartına bağlanması, Anayasal güvence altına alınan yargı erkinin bağımsızlığı hususunu tartışma konusu haline getirmektedir. Bu kapsamda, vergi kaçakçılık suçunda soruşturma ve kovuşturma şartı olarak mütalaa veya görüş kapsamında idareye verilen yetkinin varlığı söz konusudur. Dava şartı olarak mütalaa ve görüş bildirimi idari makamlar tarafından gerçekleştirilen idari bir işlemdir. VUK m. 367 düzenlemesinde vergi kaçakçılık suçları için Cumhuriyet savcılığı tarafından kamu davasının açılması idari makamların iznine bağlı olduğu anlamı çıkarılabilmektedir. Bu durumda, idari makamların yargı erkine müdahalesi şeklinde oluşan algı, ceza muhatabının yargı bağımsızlığına olan güvenini zedeleyebilmektedir.

\section{Kaynakça}

Acar, C. (2020), "Yargıtay Kararları Kapsamında Kaçakçılık Suçu", Uluslararası Sosyal Araştırmalar Dergisi, 13 (75), 671-688.

Ağar, S. (2005), Sahte ve Muhteviyatı İtibariyle Yanıltıcı Belge Düzenleme veya Kullanma Suçları, TBB Dergisi, 58, 273-371.

Ağar, S. (2016), Vergi Kaçakçılığı Kapsamında Defter ve Belgeleri ibraz Etmeme Suçu, Seçkin Yayınları, Ankara.

Akdeniz, D. (2018), "Sahte ve Muhteviyatı İtibariyle Yanıltıcı Belge Düzenleme ve Kullanma Suçunda Manevi Unsur", Adnan Menderes Üniversitesi Sosyal Bilimler Enstitüsü Dergisi, 5 (1), 90-105.

Akkaya, M. (2000), “Vergi Mahkemesi ve Ceza Mahkemesi Kararlarının Etkileşimi Üzerine Bir Inceleme", Ankara Üniversitesi Hukuk Fakültesi Dergisi, 49 (1), 85-96.

Alacakaptan, U., (1975), Suçun Unsurları, Ankara Üniversitesi Hukuk Fakültesi Yayınları, No. 372, Ankara.

Arslaner, H. (2017), Vergi Kabahat ve Suçlarının Unsurları, Ekin Yayınevi, Bursa.

Baykara, B. (2009), Teori ve Pratik Yönleriyle Vergi ve Vergi Ceza Hukuku, Maliye ve Hesap Uzmanlığı Derneği, Ankara.

Bayraklı, H. H. (2019), "Vergi Kaçakçılık Suçlarında Teşebbüs”, TAAD, 10 (37), 1-23.

Bayraklı, H. H. (2020), Vergi Yargılama Hukuku, Celepler Matbaacılık, 7. Baskı, Afyonkarahisar.

Bilici, N. (2020), Vergi Hukuku, Savaş Yayınevi, 50. Baskı, Ankara.

Candan, T. (2019), Vergisel Kabahatler ve Suçlar, Yetkin Yayınları, Ankara.

Çavuş, A. (2016), Suç Genel Teorisi Işığında Vergi Kaçakçılığı Suçları, Beta Basım, İstanbul.

Donay, S. (2008), Ceza Mahkemesinde Yargılanan Vergi Suçları, Beta Basım, Haziran, İstanbul.

Erdem, T. (2011), 6009 sayılı Kanun'la Yapılan Değişiklikler Sonrasında Vergi Incelemesi, Yaklaşım Yayınları, Ankara. 
Hatipoğlu, M. \& Parlar, A. (2005), Özel Ceza Yasaları Uygulamalarında Ekonomik ve Ticari Suçlar, Turhan Kitabevi, Ankara.

https://sozluk.gov.tr/.

Karaarslan, M. (2006), “Ceza Mevzuatında Yapılan Değişikliklerin Vergi kaçakçılığı Suçuna Etkisi”, TBB Dergisi, 64, 115-150.

Karakoç, Y. (2019), Vergi Ceza Hukuku, Yetkin Yayınları, 2. Baskı, Ankara.

Keskin, K. S. \& Suçiçek, M. (2016), Vergi inceleme Teknikleri ve Revizyon Uygulamaları, Vergi Müfettişleri Derneği Yayını, 4. Basım, Ankara

Kızılot, Ş. \& Taş, M. (2010), Vergi Hukuku ve Türk Vergi Sistemi, 5. Baskı, Gazi Kitabevi, Ankara.

Kırmaz, B. (2015), "Yargıtay İçtihatları Işığında Vergi Kaçakçılığı Suçlarında Suç Tarihinin Belirlenmesi", Ankara Barosu Dergisi, 1, 329-340.

Köşşekoğlu, A. (2011), “Vergi Usul Kanunu'nun 359/B Maddesinde Düzenlenen Vergi Kaçakçılığı Suçu", Adalet Dergisi, 39, Ocak.

Mutluer, K. \& Kuzeyli, M. N. D. (2019), Vergi Hukuku Genel ve Özel Hükümler, Yetkin Yayınları, Ankara.

Mutluer, M. K. (2008), Vergi Genel Hukuku, İstanbul Bilgi Üniversitesi Yayınları, 2.Baskı, İstanbul.

Ok, N. \& Gündel, A. (2002), Vergi Kaçakçılığı Suçları, Seçkin Yayınları, Ankara.

Öz, E. \& Armağan, A. (2018), "Yargı Organları Kararlarına Göre Vergi Kaçakçılığı Suçlarını Önlemede Adli Vergi Cezalarının Rolü", TAAD, 9 (33), 1-38.

Özel, S., (2010), "Vergi Suçlarında Faillik Kavramı", Legal Mali Hukuk Dergisi, C. 6, S. 68, ss. $1175-1180$.

Öztürk, B. \& Yavaşlar, B., F. (2020), Vergi Kabahat ve Suçları Tasarısı, Seçkin Yayıncılık, Ankara.

Sarıcaoğlu, E. (2018), "Vergi Affından Yararlanan Mükellef İçin Mütalaa Geri Alınabilir Mi?”, TBB Dergisi, 134, 217-256.

Şentürk, A., G. (2019), "Vergi Kaçakçııık Suçlarının Yargılama Şartı Olan “Mütalaa”, Bir İdari İşlem Olarak İdari Yargı Denetimine Tabi Olmalıdır", http://www.agencerhukuk.com/067.pdf.

Şenyüz, D. (2012), Vergi Ceza Hukuku, Ekin yayınevi, 6. Basım, Bursa.

Şenyüz, D. (2016), "Vergi Kaçakçılığı Suçunda Dava Şartı Olarak Mütalaa/Görüş", Izmir Barosu Dergisi, 81 (2), 13-50.

Taştan, M. (2013), “Vergi Kaçakçılık Suçlarından Sahte Belge Kullanma Suçunda Cezai Sorumluluk, Soruşturma ve Kovuşturma Yöntemi", Terazi Hukuk Dergisi, 8 (85), 37-45.

Üstün, S. (2001), "Cezaî Yaptırım Gerektiren Vergi Suçları ve Yargılama Usûlü", Selçuk Üniversitesi Hukuk Fakültesi Dergisi, 9 (3-4), 293-323.

Yüce, M. (2018), Vergi Kaçakçılığı Suçu ve Yargılama Usulü, Adalet Yayınevi, 1. Baskı, Ankara. 
Etik Beyanı: Bu çalışmanın tüm hazırlanma süreçlerinde etik kurallara uyulduğunu yazarlar beyan eder. Aksi bir durumun tespiti halinde Fiscaoeconomia Dergisinin hiçbir sorumluluğu olmayıp, tüm sorumluluk çalışmanın yazarlarına aittir.

Ethics Statement: The authors declare that ethical rules are followed in all preparation processes of this study. In case of detection of a contrary situation, Fiscaoeconomia has no responsibility and all responsibility belongs to the authors of the study. 
Çiftçi, T. E. (2021). Vergi kaçakçılık suçlarında soruşturma evresi.

Fiscaoeconomia, 5(2), 630-651 doi: 10.25295/fsecon.873942

\section{Investigation Phase in Tax Evasion Crimes}

\section{Taha Emre çifTçi}

\section{Extended Abstract}

Taxes aim to provide effective financing of public services that emerge as social needs. Individuals with financial ability contribute to the provision of public services by paying taxes. In this way, a relationship between governments and individuals arises due to taxes. Complete and timely collection of taxes are of great importance for governments, because taxes are nature financial resources. Accordingly, various duties are imposed on the taxpayers who are tax debtors as a result of this tax relationship. These obligations, supported by the power of enforcement by the law maker, are expected to be fulfilled by the taxpayers.

Some disputes may arise between the taxpayers and governments on the basis of the tax relationship. As the basis of the tax relationship is based on debt and receivables, sanctions are foreseen for violation of the rights and obligations given to the parties by law. Sanctions to be applied to those who acts against tax laws; are the penalties for tax offense and / or tax misdemeanor. The term of tax misdemeanors are based on the loss of tax that may arise due to the failure of taxpayers' tax obligation and the danger of tax loss from tax payers. These misdemeanors include mild sanctions to maintain administrative order. However, the sanction imposed by the tax administration within the framework of administrative procedures is an administrative fine. Since tax crimes involve acts disturbing public order, the sanction of these crimes is heavier than the offenses. The treatment of penalties for acts of tax crimes is carried out through criminal courts. In other words, the dispute arising in such heavy actions will be resolved by the judicial bodies. The trial of tax fraud crimes will be made according to the provisions of the Code of Criminal Procedure.

Heavy sanctions that are arranged on tax crimes will be effective in providing legal benefits. Within the scope of tax crimes, especially the acts of tax evasion can cause the loss of income for governments. In addition, considering that the financing of public services is mostly covered by taxes, if there is tax evasion crimes then the treasury of governments will face losses. And this will further damage the society due to possible budget deficit. However, the deterrent feature of heavy sanctions in tax evasion crime also plays an active role in the prevention of crime. In this respect, the weight of the sanction is important in terms of ensuring the legal benefit and public order in tax evasion crime.

Crimes requiring imprisonment and the penalties related to these crimes are included in the "Crimes and Penalties" section of the Fourth Book of the Tax Procedure Law of Turkey (TPL). In addition, "Smuggling Crimes and Penalties" included in this section includes the criminal acts subject to the most severe sanctions within the scope of tax crimes and penalties.

Tax evasion crimes comes into play when the violation of the crime types specified in clause 359 of the Tax Procedure Law (TPL). The ability to prosecute as a result of tax evasion crimes is bound by some conditions by the legislator. In this context, the clause of 367 of the Tax Procedure Law is a regulation that includes investigation and prosecution conditions for acts of smuggling. This regulation stipulated an opinion or opinion requirement in order for the tax evasion crimes to proceed to the trial stage. 
Çiftçi, T. E. (2021). Vergi kaçakçılık suçlarında soruşturma evresi.

Fiscaoeconomia, 5(2), 630-651 doi: 10.25295/fsecon.873942

\begin{abstract}
Tax evasion proceedings is initiated with the participation of persons who have tax inspection authority in accordance with the clause of 367 of TPL. Persons with tax inspection authority have been given certain powers in accordance with the same article. In addition, persons authorized to conduct tax inspection are defined in clause of 367 of TPL as tax inspectors and assistant tax inspectors and other officials authorized for tax inspection. In this context, according to the clause of 359 of TPL, the tax inspectors and assistant tax inspectors should be notified directly to the tax inspectors and tax inspector assistants, or other officials authorized to inspect the tax office by the head of the tax office or the office of the chief public prosecutor, with the opinion of the persons authorized for tax inspection.
\end{abstract}

The provision of $367 / 1$ of Tax Procedure Law imposes the obligation to notify the Public Prosecutor's Office in case of detection of tax evasion for persons authorized to examine tax. As a matter of fact, the condition of the notification obligation is also stated in the clause of $367 / 1$ of TPL. Accordingly, the opinion of the Report Evaluation Commission is requested in case of detection of smuggling by persons authorized for tax inspection. The Notion of TPL constitutes the requirement to notify the public prosecutor of the tax evasion crime by the persons specified in 367/1 clause.

Tax evasion crimes investigation and prosecution are conditioned in accordance of the clause of 367. This provision of law is a regulation that includes the investigation and prosecution conditions in case of detection of a tax evasion crime. In the case of tax evasion acts listed in the clause of 359 in TPL are detected by the persons authorized to examine the tax, the notification and notion are submitted to the Office of the Chief Public Prosecutor, constituting a condition of investigation and prosecution. In addition, in the event that the tax evasion crime is learned by the Office of the Chief Public Prosecutor, which requests a tax examination by informing the tax administration and obtaining an opinion in this context is a condition of investigation and prosecution.

It is not possible for the judiciary to have competence in a technical and specialist area such as tax. The expert opinion that will guide the judicial power to decide during both the investigation and prosecution stages of the tax evasion crime and perpetrators is important. In this regard, in tax evasion crimes, the opinion or opinion by the legislator as a condition of lawsuit arranged in the clause of 367. Notion/opinion and tax audit reports are documents prepared and reported by experts in the field of tax. The preparation of the opinion by the Report Evaluation Commissions and the preparation of the tax audit reports by the persons authorized to examine the tax are guiding the decision of the Public Prosecutor during the investigation phase of the crime and the perpetrator. However, during the investigation phase, the public prosecutor's office is not bound by the opinion and tax audit reports. The public prosecutor will decide whether to open a public lawsuit within the framework of the researches and evidence obtained against the tax evasion crime and its perpetrator.

The fact that the investigation and prosecution phase of tax evasion crimes and perpetrators are subject to the notion of administrative act makes the issue of the independence of the judiciary under constitutional debate into question. In this context, the existence of the authority given to the administration within the scope of notion or opinion as a condition for investigation and prosecution in tax evasion crime. As a condition of the case, notion and statement of opinion is an administrative action carried out by administrative authorities. The 
Çiftçi, T. E. (2021). Vergi kaçakçılık suçlarında soruşturma evresi.

Fiscaoeconomia, 5(2), 630-651 doi: 10.25295/fsecon.873942

regulation of 367 of TPL can be inferred that the public prosecution for tax evasion crimes is subject to the permission of the administrative authorities. In this case, the perception formed as the intervention of the administrative authorities to the judicial power may damage the confidence of the criminal interlocutor in the independence of the judiciary. 